\title{
LEGAL PROTECTION OF DOCTORS IN PROVIDING HEALTH SERVICES
}

\author{
Bambang Tri Bawono \\ Sultan Agung Islamic University \\ Bambang@unissula.ac.id
}

\begin{abstract}
Cases of alleged malpractice committed by doctors or health workers have become an interesting issue that has been widely discussed by the public. Malpractice is basically due to the emergence of differences in perception between patients and doctors or health workers. The research method used in this study is library research, library research limits its activities to library collections. While the approach used in this study is normative juridical, the results of the study mentioned that the standards that must be met by doctors to obtain legal protection are professional standards, operational procedures standards, and medical service standards. These three standards, doctors are also obliged to make informed consent as part of health service standards, and carry out the obligations as contained in Article 51 of Law No. 29 of 2004 concerning Medical Practice. In addition, doctors can be free from allegations of medical malpractice when providing health services in accordance with professional standards and operational procedures, providing medical services based on informed consent and the principle of non-vit inura volenti law or the assumption of risk, respectable minority rules and error of in judgment, as well as contribution negligence.
\end{abstract}

Keywords: Doctors, Health service, Legal Protection.

\section{A. INTRODUCTION}

In recent years, cases of alleged malpractice committed by doctors or health workers have become an interesting issue that has been widely discussed by the public. The allegations about malpractice actions carried out by doctors or health workers, eventually resulted in many people starting to get suspicious about the occurrence of moral degradation committed by doctors, so that it is considered irresponsible in carrying out his profession. Although the allegations of malpractice do not necessarily show the truth about the occurrence of malpractice, but the existence of such allegations has indirectly given a frightening impression to doctors or health workers to provide health services. ${ }^{1}$ Alleged cases of malpractice reported to the Indonesian Medical Council (KKI) in the period 2006 to 2015 have reached 317 cases. Of the 317

1 Ari Yunanto, Hukum Pidana Malpraktik Dokter; Tinjauan dan Perspektif Medikolegal, Pt. Andi, Yogyakarta, 2010, P.3 
cases, 76 cases were performed by surgeons, 27 cases by pediatricians, 56 cases by obstetricians (obstetricians), and 114 cases by general practitioners. ${ }^{2}$

Allegedly the occurrence of malpractice is basically due to the emergence of differences in perception between patients and doctors or health workers. This difference in perception generally arises because of the inability of patients to understand that medical efforts are efforts that are full of uncertainty and the results cannot be taken into account mathematically because they are related to other factors beyond the physician's control and control to control them. These factors for example are due to endurance, type and virulence of the disease, the body's defense mechanisms, individual responses to drugs, patient compliance with procedures and doctor's advice, and other things that can cause adverse effects on the patient's condition. While on the other hand, many people are of the view that medical efforts made by doctors or health workers are the only variables that can affect the patient's condition, so that when death occurs, the condition worsens, or even new problems arise, this raises the notion that medical efforts undertaken by doctors are the only cause for these adverse conditions. Even if reflecting on even the best and most expensive medical efforts, then these efforts may not necessarily guarantee the patient's recovery. Based on that fact, it is not wrong if health experts state that "medicine is a science of the uncertainty, an art of the probability" which means that medicine is the science of uncertainty, the art of probability. ${ }^{3}$

Based on this fact, it is undeniable that Article 66 paragraph (1) of Law no. 29 of 2004 concerning Medical Practices which states that everyone who knows his interests are harmed by the actions of a doctor or dentist in carrying out medical practice can complain in writing to the Chairperson of the Indonesian Medical Disciplinary Honorary Council, providing legal protection to patients in order to obtain health services in accordance with standards so that their interests are not harmed by doctors or health workers. However, the existence of this provision also indirectly becomes a turning point of concern for doctors or health workers, because many people do not understand, that the legal relationship established between patients and doctors is an engagement effort (verbintenis inspection), so that doctors or health workers do not promising the results of healing that must be given, but only burdened with the obligation to make the right effort and in accordance with predetermined standards. ${ }^{4}$ Furthermore, even the results of Hardisman's research entitled, "Public Opinion on Medical Malpractice" states that public opinion about medical malpractice adopts the theory of consequentialism that focuses on the consequences experienced by patients and does not consider actions taken by doctors, even though it is based on moral values and medical standards. ${ }^{5}$

The existence of such a public view is certainly very burdensome for the medical profession, because doctors do not have the ability to provide healing,

2 Setyo Tresnadi, Perlindungan Hukum Profesi Dokter dalam Penyelesaian Sengketa Medis, Jurnal Pembaharuan Hukum, Vol. IV, No. 1, 2017, P.24-40.

3 Sofwan Dahlan, Malpraktik; Simposium Pencegahan dan Penanganan Kasus Dugaan Malpraktik, Badan Penerbit Universitas Diponegoro, Semarang, 2006, P.81

4 Ari Yunanto, Op.Cit, P.5.

5 Hardisman, Opini Masyarakat tentang Malpraktek Kedokteran, Majalah Kedokteran Andalas, No.1, Vol. 36, 2012, P. 84. 
but only have the expertise and knowledge to provide health services in accordance with the standards determined by law.

\section{B. RESEARCH METHODS}

The research method used in this study is library research. Zed Mestika defines library research as library research that utilizes sources from the library to obtain research data, so library research limits its activities to library collections. ${ }^{6}$ While the approach used in this study is normative juridical. In Soerjono Soekanto's view, normative juridical research is a series of legal research conducted by examining library material or secondary data as a basic material to be investigated by conducting a search of regulations and literature relating to the problem under study.

While the legal materials used in this study consisted of primary and secondary legal materials. Primary legal material consists of legislation, official records or treatises relating to this research. Whereas secondary legal materials are related to legal materials that provide explanations to primary legal materials, such as books, literature, articles, papers and other materials taken from legal experts.

\section{DISCUSSION}

\section{Standards that Doctors Must Have in Providing Health Services}

Article 1 paragraph (1) of Law No. 29 of 2004 concerning Medical Practices states that the practice of medicine is a series of activities carried out by doctors or dentists towards patients in conducting health efforts. In carrying out health efforts, of course the doctor must have a clear measure, so that it can be said that the practice is in the category of malpractice or not. This measure is certainly based on the provisions set out in the legislation and the code of ethics of the medical profession. The existence of this provision will certainly provide certainty and legal protection for doctors as providers of health services and also patients as parties who receive health services. Provisions regarding medical practices that must be in accordance with the medical code of ethics are based on Article 1 paragraph (11) of Law no. 29 of 2004 concerning Medical Practice which states that the profession of medicine or dentistry is a medical work carried out based on a science, competencies obtained through tiered education, and a code of ethics that is serving the community. Referring to this provision, the doctor or dentist has an obligation to obey and comply with the medical code of ethics, so that when the health services provided by doctors do not comply with the medical code of ethics, the doctor may be subject to sanctions for violating medical ethics.

The other side of it, to get legal protection as stated in the law, the doctor or dentist is obliged to provide health services in accordance with professional standards and operational procedure standards. This is based

6 Mustika Zed, Metodologi Penelitian Kepustakaan, Yayasan Obor Indonesia, Jakarta, 2008, P. $1-2$.

7 Soerjono Soekanto dan Sri Mamudji, Penelitian Hukum Normatif (Suatu Tinjauan Singkat), Rajawali Pers, Jakarta, 2001, P. 13 
on Article 50 letter (a) of Law No. 29 of 2004 concerning Medical Practice which says that doctors or dentists in carrying out medical practice have the right to obtain legal protection as long as carrying out their duties in accordance with professional standards and operational procedure standards. The definition of professional standards contained in the explanation of Article 50 of Law no. 29 of 2004 concerning Medical Practices which states that professional standards are the minimum limits of ability (knowledge, skills, and attitude) that must be mastered by an individual to be able to carry out their professional activities in the community independently created by professional organizations. Hermien Hadiati Koeswadji in this case also defines professional standards as the intention or goodwill of doctors based on professional ethics and based on a standard agreed upon by professional supporters. Leenen and the Dutch health law expert Van der Mijn argued that in carrying out his profession, a doctor or health worker needs to hold fast to the following three things: ${ }^{8}$

a. Authority.

The authority of a doctor or health worker is the legal authority (rechtsbevoegheid) owned by a doctor or health worker to carry out his work. ${ }^{9}$ By their nature, the authority to carry out medical actions is based on material authority and formal authority. Material authority is authority based on expertise possessed by doctors. While formal authority is the authority set forth in the legislation. Both of these authorities are an inseparable unit for doctors to be able to carry out the medical profession. A doctor must first have the material authority or expertise by carrying out medical education. However, despite having expertise, a doctor does not have the authority to practice medicine, before having a registration certificate (STR) and a practice permit (SIP). ${ }^{10}$ If the doctor or dentist does not fulfill one or both of these obligations, the doctor or dentist has violated the medical administration because he does not have the STR and SIP as regulated in Articles 75 and 76 of Law No. 29 of 2004 concerning Medical Practice.

b. Average Ability.

Syahrul Machmud stated that average ability is the minimum ability of science that must be possessed by a doctor or dentist. Average ability does not have to be measured by a doctor or dentist who is very genius, but it is also not measured by a doctor or dentist who has little knowledge. So the average ability must be measured from the scientific knowledge of an average doctor or dentist. ${ }^{11}$ The discussion on average ability is explained in the explanation of Article 50 of Law No. 29 of 2004 concerning Medical Practice, namely the ability of knowledge (knowledge), skills (skills), and attitude (attitude).

8 Adami Chazawi, Malpraktik Kedokteran, Penerbit Sinar Grafika, Jakarta, 2016, P. 24

9 Endang Kusuma Astuti, Transaksi Terapeutik dalam Upaya Pelayanan Medis di Rumah Sakit, Citra Aditya Bakti, Bandung, 2009, P. 35.

10 Adami Chazawi, Malpraktik Kedokteran; Tinjauan Norma dan Doktrin Hukum, Bayu Media Publishing, Malang, 2007, P. 2

11 Syahrul Machmud, Penegakan Hukum dan Perlindungan Hukum Bagi Dokter yang Diduga Melakukan Medikal Praktek, Penerbit Cv. Mandar Maju, Bandung, 2008, P.148 
c. General accuracy.

General accuracy in carrying out health services is that a doctor or dentist is required to act carefully, be careful, and not be careless. As for the general measurement of accuracy can be seen from the general assessment. A general assessment is if a group of doctors will take the same action in the same situation and condition. This same action in the same situation and condition is used as a measure of general accuracy. ${ }^{12}$

In addition to professional standards, doctors or dentists are also obliged to provide health services in accordance with standard operating procedures. Standard operational procedures are a set of instructions or standardized steps for completing a particular routine work process. Standard operational procedures provide the right and best steps based on mutual consensus to carry out various activities and service functions created by health service facilities based on professional standards. ${ }^{13}$ This procedural operational standard aims to regulate the extent to which the limits of authority and ethical and legal responsibilities of doctors to patients, as well as the responsibilities of hospitals to medical staff and vice versa. Veronica Kumalawati defines standard operating procedures as procedures outlined by health service providers from each specialization whose application is adapted to existing facilities and resources. ${ }^{14}$ In addition to professional standards and operational procedure standards, no less important thing that must be given by doctors is medical service standards. Article 44 of Law No. 29 of 2004 concerning Medical Practice states that:

1) Doctors or dentists in carrying out medical practices must follow medical or dental service standards.

2) Service standards as referred to in paragraph (1) are distinguished according to the type and strata of health service facilities.

3) Service standards for doctors or dentists as referred to in paragraph (1) and paragraph (2) are regulated by ministerial regulation.

Medical service standards are guidelines that must be followed by doctors and dentists in carrying out medical practice. Whereas what is meant by service level is the level of service with the standard of power and equipment in accordance with the capabilities provided. Further explanation regarding health service standards is regulated in Regulation of the Minister of Health of the Republic of Indonesia Number 1438 / MENKES / PER / IX / 2010 concerning Health Service Standards. The purpose of health service standards is to provide guarantees to patients

12 J. B. Suharjo B. Cahyono, Menjadi Pasien Cerdas, Pt. Gramedia Pustaka Utama, Jakarta, 2013, P. 378.

13 Adnan Murya dan Urip Sucipto, Etika dan Tanggung Jawab Profesi, Deepublish, Yogyakarta, 2019, P. 85.

14 Michelle Gabriele Monica Rompis, perlindungan hukum terhadap dokter Yang diduga melakukan medical malpraktik, Lex Crimen, Vol VI No.4 Jun 2017, P.71-78. 
to be able to obtain medical services based on scientific value in accordance with the patient's medical needs and to improve the quality of medical services provided by doctors and dentists.

Apart from such contests, one of the important things that must be done by doctors in providing health services is to make informed consent. Nusye K.I. Jayanti states that informed consent is an agreement given by a patient or guardian who is entitled to the doctor to take a medical action against the patient after the patient or guardian has received complete information and understands the action. ${ }^{15}$ Muntaha in this case states that informed consent is part of the standard of medical services that must be in place before medical treatment is performed. This is because the approval of medical action means that the parties have agreed to bind themselves to each other, so that rights and obligations arise for each party. The other side of it, the existence of this medical agreement also serves as a basis for prosecuting in the event of medical action outside of what has been agreed or promised. ${ }^{16}$ Other obligations that doctors have are also contained in Article 51 of Law Number 29 Year 2004 concerning Medical Practices which states that doctors or dentists in carrying out medical practices have obligations:

1) Providing medical services in accordance with professional standards and standard operating procedures and patient's medical needs.

2) Referring patients to doctors or other dentists who have better skills or abilities, if unable to conduct an examination or treatment.

3) Keep everything he knows about the patient, even after the patient has died.

4) Carry out emergency relief on the basis of humanity, except if he is sure there is someone else on duty and able to do it.

5) Add knowledge and follow the development of medical science or dentistry.

\section{Legal Protection of Doctors in Providing Health Services}

According to Philipus M. Hadjon, legal protection is a protection given to legal subjects in the form of legal instruments both preventive and repressive, both written and unwritten. In this case, Sudikno Mertokusumo also provides a definition of legal protection as all efforts made to ensure legal certainty based on all regulations or rules that exist in a common life. ${ }^{17}$ Likewise, legal protection according to Satjipto Rahardjo is the protection of human rights that are harmed by others and given to the community so that they can enjoy all the rights provided by law. ${ }^{18}$

15 Nusye K.I. Jayanti, Penyelesaian Hukum dalam Malpraktek Kedokteran, Pustaka Yustisia, Yogyakarta, 2009, P. 89.

16 Muntaha, Hukum Pidana Malapraktik Pertanggungjawabn dan Penghapusan Pidana, Sinar Grafika, Jakarta, 2017, P. 26.

17 Novita Listyaningrum, Informed Consent dalam Perlindungan Dokter yang Melakukan Euthanaisa, Journal Advokasi, Vol. 6, No. 1, 2016, P.30.

18 Satjipto Rahardjo, IImu Hukum, Pt. Citra Aditya, Bandung, 2000, P. 54. 
Article 66 paragraph (1) of Law No. 29 of 2004 concerning Medical Practice states that anyone who knows his interests are harmed by the actions of a doctor or dentist in carrying out medical practice can report in writing to the Chairperson of the Indonesian Medical Disciplinary Honorary Council. The existence of this provision means that the law of medical practice has provided legal protection to patients so that their interests are not harmed by doctors. It's just that, of course, not only patients get legal protection from the Law, but doctors also get legal protection in carrying out their duties as a medical profession. In connection with the existence of legal protection, there are several things that can free a doctor or dentist from lawsuits. Are as follows:

a. Has provided health services in accordance with operational standards and procedural standards. Referring to Article 50 letter a of Law No. 29 of 2004 concerning Medical Practice which states that doctors or dentists in carrying out medical practices have the right to obtain legal protection as long as carrying out their duties in accordance with professional standards and operational procedure standards. The existence of this provision provides legal protection for doctors or dentists when they have performed health services in accordance with professional standards and operational procedure standards.

b. Legal Protection Based on Informed Consent. Article 6 of the Regulation of the Minister of Health of the Republic of Indonesia Number 290 / MENKES / PER / III / 2008 concerning Approval of Medical Measures stipulates that granting approval for medical measures does not eliminate legal liability in the case of proven negligence in carrying out medical actions that result in harm to patients. Based on this provision, the approval of medical action does not necessarily eliminate the doctor's liability, when it is proven that there is negligence of medical actions that result in harm to patients. Although the existence of informed consent can still lead to accountability when there is negligence by the doctor in providing medical treatment, but legally informed consent has an important role in health care. This is because the existence of informed consent is permission given by the patient to the doctor to provide medical treatment. A medical action such as surgery that is not accompanied by informed consent, resulting in the doctor's actions can be equated with acts of mistreatment as contained in Article 351 of the Criminal Code. Similarly, in anesthesia which is not accompanied by informed consent, then this action can also be equated with the act of making someone in a state of unconsciousness, which means it is in accordance with committing violence as contained in Article 89 of the Criminal Code. ${ }^{19}$ Article 89 of the Criminal Code states that making people faint or powerless, then equated with violence.

c. This reality is certainly different from the situation of emergency patients, so that the doctor is obliged to provide help, although not accompanied by informed consent from the patient. This is based on 
Article 4 paragraph (1) Permenkes RI No. 290 / MENKES / PER / III / 2008 concerning Approval of Medical Measures which states that in an emergency situation, to save patients and / or prevent disability, approval of medical action is not required. Furthermore, even if doctors or health workers do not provide assistance to emergency patients on the grounds of the absence of informed consent, then doctors or health workers may be subject to sanctions as contained in Article 190 of Law No. 36 of 2009 concerning Health. Article 190 of Law No. 36 of 2009 concerning Health explains that the leaders of health service facilities and / or health workers who carry out practices or work at health service facilities that intentionally do not provide first aid to patients who are in an emergency situation as referred to in Article 32 paragraph (2) or Article 85 paragraph (2) shall be sentenced to a maximum imprisonment of 2 (two) years and a maximum fine of Rp.200,000,000.00 (two hundred million rupiah).

d. The other side of it, legal protection for doctors who have received medical approval certainly gives the sense that the patient has given permission to the doctor to take medical action on his body. Especially when referring to the understanding of the approval of medical measures as mentioned in Article 1 of the Republic of Indonesia Ministerial Regulation No. 290 / MENKES / PER / III / 2008 concerning the Approval of Medical Measures, then an approval of medical action must be given after the patient or the patient's family gets a complete explanation of the medical actions that will be performed on the patient. In this regard, as discussed earlier, that the agreement between the doctor and the patient is verbintenis inspection, so that the doctor is not burdened to heal the patient, but only does everything possible to cure the patient in accordance with professional standards and operational procedure standards. A medical action certainly does not escape medical risks, so that this agreement becomes the basis for medical actions to be performed by doctors. The existence of informed consent given by the patient is proof that the patient or the patient's family has been willing to take a medical action whose main purpose is to save the patient. The existence of this agreement certainly does not escape with all aspects arising from medical treatment, both the benefits of medical treatment and medical risks that are not expected to occur. In this case, if an unwanted medical risk occurs, then with the informed consent, the doctor only needs to prove that his risky actions have obtained approval from the patient or the patient's family. This is because there is a doctrine that reads "volenti non vit inura" which is also known as the assumption of risk. $^{20}$ This doctrine gives the understanding that there is already a serious risk for the person concerned, even though he is still willing to bear all the risks. This teaching is based on the idea that anyone who already knows of a serious risk, and voluntarily still be willing to bear the risk, so if the risk does occur, then he can not sue again. Although

20 Syahrul Machmud, Op.Cit P.167. 
in the case of medical risks, doctors have had such a legal basis. However, doctors still have a moral obligation to carry out the best medical treatment. This is caused by the emergence or absence of medical risk also still depends on the medical actions taken by doctors, whether it is in accordance with professional standards and operational procedure standards or not. This is very reasonable considering the doctor's actions that are not in accordance with professional standards and operational procedure standards whatever form and reasons can be held accountable. ${ }^{21}$

e. Respectable Minority Rules and Error of Judgment. In a treatment effort, of course there is often a disagreement to provide appropriate therapy for specific medical situations, so that it may be that the approach to an illness has differences between one doctor and another doctor. However, the existence of this difference remains based on science that can be accounted for. Based on this situation, a legal theory emerged by the court called the respectable minority rule, ie a doctor is not considered to be negligent if he chooses one of the many ways of treatment that is recognized. The choice of one of these methods turned out to lead to errors in medical actions, thus creating a new theory called medical judgment or medical error, which means that the choice of medical actions based on professional standards turned out to be a wrong choice. This doctrine states that physician choice errors cannot be accounted for because there is no neglect in this choice. Unless this doctor does not follow the medical standards commonly used by his peers. ${ }^{22}$

f. Contribution Negligence. In addition to some of the above, the doctor is also not to blame, if the doctor is unsuccessful in dealing with his patients, when the patient is not cooperative because he does not obey the doctor's instructions, does not explain honestly about the history of the disease he has suffered, the drugs he had taken during sick, or refuse the agreed treatment. This is considered as the fault of a plural patient called contribution negligence or the patient is also guilty. ${ }^{23}$

\section{CONCLUSION}

Standards that must be met by doctors in providing health services in order to obtain legal protection are professional standards, operational procedures standards, and medical service standards. In addition to these three standards, doctors are also obliged to make informed consent as part of health service standards, and carry out the obligations as contained in Article 51 of Law No. 29 of 2004 concerning Medical Practice. In addition doctors are free from allegations of malpractice when they have provided health services in accordance with professional standards and operational procedures, providing

21 Sutarno, Hukum Kesehatan; Eutanasia, Keadilan, dan Hukum Positif di Indonesia, Setara Press, Malang, 2014, P. 58.

22 Syahrul Machmud, Op.Cit P.167.

23 Ibid. 
medical services based on informed consent and the principle of non vit inura volentiary law or the assumption of risk, respectable minority rules and error of judgment, and contribution negligence.

\section{BIBLIOGRAPHY}

\section{Book:}

Adami Chazawi, 2007, Malpraktik Kedokteran; Tinjauan Norma dan Doktrin Hukum, Bayu Media Publishing, Malang;

Adami Chazawi, 2016, Malpraktik Kedokteran, Penerbit Sinar Grafika, Jakarta;

Adnan Murya dan Urip Sucipto, 2019, Etika dan Tanggung Jawab Profesi, Deepublish, Yogyakarta;

Ari Yunanto, 2010, Hukum Pidana Malpraktik Dokter; Tinjauan dan Perspektif Medikolegal, Pt. Andi, Yogyakarta;

Endang Kusuma Astuti, 2009, Transaksi Terapeutik dalam Upaya Pelayanan Medis di Rumah Sakit, Citra Aditya Bakti, Bandung;

Hardisman, Opini Masyarakat tentang Malpraktek Kedokteran, Majalah Kedokteran Andalas, No.1, Vol. 36, 2012;

J. B. Suharjo B. Cahyono, 2013, Menjadi Pasien Cerdas, Pt. Gramedia Pustaka Utama, Jakarta;

Michelle Gabriele Monica Rompis, perlindungan hukum terhadap dokter Yang diduga melakukan medical malpraktik, Lex Crimen, Vol VI No.4 Jun 2017;

Muntaha, 2017, Hukum Pidana Malapraktik Pertanggungjawabn dan Penghapusan Pidana, Sinar Grafika, Jakarta;

Mustika Zed, 2008, Metodologi Penelitian Kepustakaan, Yayasan Obor Indonesia, Jakarta;

Novita Listyaningrum, Informed Consent dalam Perlindungan Dokter yang Melakukan Euthanaisa, Journal Advokasi, Vol. 6, No. 1, 2016;

Nusye K.I. Jayanti, 2009, Penyelesaian Hukum dalam Malpraktek Kedokteran, Pustaka Yustisia, Yogyakarta;

Satjipto Rahardjo, 2000, Ilmu Hukum, Pt. Citra Aditya, Bandung, 2000;

Setyo Tresnadi, Perlindungan Hukum Profesi Dokter dalam Penyelesaian Sengketa Medis, Jurnal Pembaharuan Hukum, Vol. IV, No. 1, 2017;

Soerjono Soekanto dan Sri Mamudji, 2001, Penelitian Hukum Normatif (Suatu Tinjauan Singkat), Rajawali Pers, Jakarta;

Sofwan Dahlan, 2006, Malpraktik; Simposium Pencegahan dan Penanganan Kasus Dugaan Malpraktik, Badan Penerbit Universitas Diponegoro, Semarang;

Sutarno, 2014, Hukum Kesehatan; Eutanasia, Keadilan, dan Hukum Positif di Indonesia, Setara Press, Malang;

Syahrul Machmud, 2008, Penegakan Hukum dan Perlindungan Hukum Bagi Dokter yang Diduga Melakukan Medikal Praktek, Penerbit Cv. Mandar Maju, Bandung; 